\title{
Effects of Pathogen Density, Soil Moisture, and Soil pH on Biological Control of Clubroot in Chinese Cabbage by Heteroconium chaetospira
}

K. Narisawa, Plant Biotechnology Institute Ibaraki Agricultural Center, Ago, Iwama, Nishi Ibaraki 319-0292 Japan; M. Shimura, Department of Environmental Biotechnology, Graduate School of Agriculture, Tohoku University, Sendai 981-8555, Japan; F. Usuki, Plant Biotechnology Institute Ibaraki Agricultural Center, Ago, Iwama, Nishi Ibaraki 319-0292 Japan; and S. Fukuhara and T. Hashiba, Department of Environmental Biotechnology, Graduate School of Agriculture, Tohoku University, Sendai 981-8555, Japan

\begin{abstract}
Narisawa, K., Shimura, M., Usuki, F., Fukuhara, S., and Hashiba, T. 2005. Effects of pathogen density, soil moisture, and soil $\mathrm{pH}$ on biological control of clubroot in Chinese cabbage by Heteroconium chaetospira. Plant Dis. 89:285-290.

The effects of soil moisture and $\mathrm{pH}$, and pathogen resting spore density, on the effectiveness of the biological control of clubroot by the fungal endophyte Heteroconium chaetospira was evaluated in greenhouse and field experiments. Conditions favoring disease development included low $\mathrm{pH}$ (5.5) and high soil moisture content (80\%), with significant reductions in the disease being observed at a higher $\mathrm{pH}(6.3$ and 7.2$)$ and lower soil moisture content (40 and 60\%). In greenhouse tests, H. chaetospira effectively controlled clubroot (reducing the disease by 90 to $100 \%$ ) at pathogen resting spore densities of $10^{4}$ and $10^{5}$ spores/g of soil at all soil $\mathrm{pHs}$ tested $(5.5,6.3$, and 7.2). However, when the resting spore density was $10^{6}$ spores/g of soil, plants were severely diseased, regardless of treatment, and $H$. chaetospira had no effect on disease. At a soil moisture content of $40 \%$, disease occurrence was low, regardless of pathogen spore density, but disease was significantly lower in $H$. chaetospira-treated plants at pathogen spore density of $10^{5}$ spores/g of soil. At $60 \%$ soil moisture content, $H$. chaetospira significantly could affect at pathogen spore densities of $10^{4}$ and $10^{5}$ but not $10^{4} / \mathrm{g}$ of soil. At $80 \%$ soil moisture content, there was no effect of $H$. chaetospira at pathogen density. In situ, the soil moisture contents were constantly adjusted to relatively low to moderate ( $\mathrm{pF} 2.2$ to 2.4 and $\mathrm{pF} 2.0$ to 2.2 ) and high (pF 1.6 to 1.8). Other environmental conditions, such as resting spore density and soil $\mathrm{pH}$, were maintained at constant levels. Control plants (not treated with H. chaetospira) showed uniformly high disease levels and proportions of diseased plants across all three moisture treatments (disease index $=72$ to 80 , proportion of diseased plants 85 to $97 \%$ ). In the field, H. chaetospiratreated plants at low soil moisture (pF 2.2 to 2.4, plot 1) had 68\% disease reduction compared with untreated controls and $49 \%$ reduction at moderate moisture $\mathrm{pF}$ ( $\mathrm{pF} 2.0$ to 2.2 , plot 2). There was no effect on disease by $H$. chaetospira at high soil moisture ( $\mathrm{pF} 1.6$ to 1.8, plot 3 ). Based on our results, $H$. chaetospira is an effective biocontrol agent against clubroot in Chinese cabbage at a low to moderate soil moisture range and a pathogen resting spore density of $10^{5}$ (or lower) resting spores per gram of soil in situ.
\end{abstract}

\section{Additional keywords: Plasmodiophora brassicae}

Clubroot of brassica crops, caused by the soilborne protozoan Plasmodiophora brassicae Woronin, is one of the most serious plant diseases in the world (9). The disease is characterized by the proliferation of galls on infected roots, which causes wilting and reduced yield. Control of the pathogen has relied on chemical control agents, predominantly methyl bromide. However, under The Montreal Pro-

Corresponding author: K. Narisawa

E-mail: knarisawa@agri.pref.ibaraki.jp

Part of this work was supported by a research grant from the Ministry of Education, Culture, Sports, Science, and Technology of Japan to T. Hashiba.

Accepted for publication 15 October 2004.

DOI: 10.1094/PD-89-0285

(C) 2005 The American Phytopathological Society tocol of 1991, methyl bromide was identified as a contributor to the depletion of the ozone layer. Accordingly, the production and trade of this chemical will be phased out by 2005. A reduction in the use of this and other chemical agents could be achieved through the development of biological control methods against pest organisms. However, so far only a few attempts have been made to develop biological control methods to control clubroot using soil fungi (1), bacteria $(2,3)$, or baiting crops (4). Consequently, a significant reduction in the incidence of clubroot using this method has not been achieved commercially.

Recently, Narisawa et al. (10) found that an isolate of the dematiaceous hyphomycete Heteroconium chaetospira (Grove) M. B. Ellis suppressed clubroot in situ. Previously reported biocontrol microorganisms, including soil fungi and bacteria, are af- fected by a suite of competitive interactions with other microorganisms of the rhizosphere community and, thus, measurements of persistence and effectiveness are problematic, if not impossible. However, $H$. chaetospira penetrates through the outer epidermal cells of its host, passes into the inner cortex, and grows throughout the cortical cells, including those of the root tip region. In this protected endophytic environment, $H$. chaetospira can grow and persist for long periods and may be less affected by microbial interactions outside the root than other biocontrol agents. In fact, when Chinese cabbage seedlings preinoculated with $H$. chaetospira were transplanted to the field, they showed a 52 to $97 \%$ reduction in clubroot compared with uninoculated controls (10). These results suggest that $H$. chaetospira may have potential as a new type of biocontrol agent for clubroot.

We previously demonstrated that $H$. chaetospira could not suppress the effects of clubroot organisms when they are unable to colonize host roots (11). In addition, we showed that commercial horticultural soils, which contain excess nutrients, retarded the growth of the fungal endophyte in Chinese cabbage seedlings (15). Therefore, appropriate growth conditions in plant nursery settings, including suitable nutrient and carbon concentrations, were developed to ensure the formation of the symbiotic association between the fungus and the host plant. The highest frequencies of colonization $(75 \%)$ were recorded when peat moss amended with $0.1 \%$ glucose was selected for nursery soils. Under these conditions, fungal hyphae developed well intracellularly in root cortical cells and none of the inoculated plants showed any typical pathogenic symptoms, thereby achieving marketable qualities (15). Accordingly, we feel that a nursery system for $H$. chaetospira-treated Chinese cabbage was attained.

Basic environmental conditions, including temperature, moisture, sunlight, and soil physical and chemical characteristics, can greatly affect the physiology of the host plant and subsequent disease development, as well as alter interactions among the plant, pathogen, and biocontrol agents in various ways (7). To control clubroot, it is essential to determine how the biological 
control agent is affected by changing environmental conditions, particularly soil moisture and $\mathrm{pH}$, as well as by the pathogen resting spore density in the soil. Hence, the objective of this study was to assess the effects of some environmental conditions, including soil moisture, soil $\mathrm{pH}$, and the pathogen resting spore density, on the effectiveness of the fungal endophyte $H$. chaetospira as a biological control agent of clubroot in Chinese cabbage.

\section{MATERIALS AND METHODS}

Chinese cabbage (Brassica campestris L.) cv. Shin-Riso (Nihon-norin Co., Tokyo), susceptible to clubroot disease, and H. chaetospira (MAFF238955), obtained from the roots of Chinese cabbage grown in a sample of soil from a wheat field at Shimodate, Ibaraki, Japan (11), were used for the experiments. Resting spores of $P$. brassicae were obtained from clubroot galls on field-grown Chinese cabbage plants at Iwama, Ibaraki, Japan, in 2001. Galls were washed with tap water and stored at $-80^{\circ} \mathrm{C}$ in plastic bags prior to use. Galls, allowed to rot at $4^{\circ} \mathrm{C}$ for 1 month to obtain viable and mature resting spores, were macerated in a homogenizer with sterile, deionized water (SDW) and centrifuged at 3,000 rpm for 10 min in a swinging-bucket rotor. The sediment was resuspended in SDW and centrifuged three times. The resting spore suspension was diluted to $1 \times 10^{9}$ spores $\mathrm{ml}^{-1}$ with SDW. A hemacytometer was used to determine spore concentrations.

$H$. chaetospira was grown on corn meal malt yeast medium (25 g of corn meal [infusion form, Difco Laboratories, Detroit, MI], $15 \mathrm{~g}$ of Bacto agar [Difco], $10 \mathrm{~g}$ of malt extract [Difco], $2 \mathrm{~g}$ of yeast extract [Difco], and 1 liter of $\mathrm{H}_{2} \mathrm{O}$ ) in petri dishes at room temperature (approximately $23^{\circ} \mathrm{C}$ ). After 4 weeks, fungal colonies were stripped from the medium and mixed with SDW to make a fungal suspension. The suspension was filtered through four layers of gauze to remove fungal hyphae and residue. The conidial suspensions $(15 \mathrm{ml})$ were mixed with $50 \mathrm{~g}$ of autoclaved peat moss $\left(121^{\circ} \mathrm{C}, 15 \mathrm{~kg} \mathrm{~cm}^{-2}\right.$ for $30 \mathrm{~min}$, liquid cycle) with 60 of $\mathrm{ml}$ nutrient medium $\left(\mathrm{NaNO}_{3}, 1 \mathrm{~g} ; \mathrm{KH}_{2} \mathrm{PO}_{4}, 1 \mathrm{~g} ; \mathrm{MgSO}_{4} \cdot 7 \mathrm{H}_{2} \mathrm{O}\right.$, $0.2 \mathrm{~g} ; \mathrm{KCl}, 0.2 \mathrm{~g}$; and $\mathrm{H}_{2} \mathrm{O}, 1$ liter) and $0.1 \%$ glucose. The final concentration of the inoculum was adjusted to $10^{4}$ conidia per $1 \mathrm{~g}$ of dry soil and $60 \%$ soil moisture content at $\mathrm{pH}$ 5.5. They were incubated at room temperature for 2 weeks to allow for the proliferation of the inoculum in the peat soil.

Chinese cabbage seed were surface sterilized by immersion in a $70 \%$ solution of ethanol for $2 \mathrm{~min}$ and a solution of sodium hypochlorite (1\% available chlorine) for 5 min. Seed then were rinsed three times with SDW and placed on $1.5 \%$ water agar (15 $\mathrm{g}$ of Bacto agar [Difco] and 1 liter of $\mathrm{H}_{2} \mathrm{O}$ ) in petri dishes. After 2 days, the ax- enically grown seedlings were transplanted to plastic nursery pots containing the soil with the inoculum (see above). Seedlings from seed sown in the mixed soil without H. chaetospira served as controls. All transplanted seedlings were incubated in a growth chamber at $23^{\circ} \mathrm{C}$ under a cycle of $16 \mathrm{~h}$ of light and $8 \mathrm{~h}$ of dark (approximately $180 \mu \mathrm{mol} \mathrm{m^{-2 }} \mathrm{s}^{-2}$ ) for 3 weeks.

Root colonization by $\boldsymbol{H}$. chaetospira. Entire root systems of Chinese cabbage seedling were recovered from the nursery pots to quantify the degree of colonization by the fungal endophyte. All roots were cut into $1.5-$ to $2.0-\mathrm{cm}$ segments. These root segments were cleared in $10 \% \mathrm{KOH}$ at $80^{\circ} \mathrm{C}$ for $20 \mathrm{~min}$, neutralized in $1 \% \mathrm{HCl}$ at $80^{\circ} \mathrm{C}$ for $20 \mathrm{~min}$, and stained with $0.05 \%$ cotton blue in $50 \%$ acetic acid. Stained root segments were mounted on a glass slide with a grid sheet and observed under a light microscope (Olympus BX50) at $\times 100$ magnification. Roots were examined along grid lines to estimate the percentage of colonization. Each grid cell was designated as either colonized or noncolonized. The degree of colonization of Chinese cabbage roots by the fungal endophyte always was assessed before transplanting.

Disease suppression in the greenhouse. Three-week-old $H$. chaetospiratreated and untreated (control) seedlings were transplanted to plastic pots containing $200 \mathrm{ml}$ of $P$. brassicae-infested nonautoclaved soil mixture (Kureha Chemical Industry Co., Tokyo) and grown in a greenhouse at 20 to $25^{\circ} \mathrm{C}$. The concentrations of resting spores of $P$. brassicae were adjusted to $1.0 \times 10^{4}, 1.0 \times 10^{5}$, or $1.0 \times 10^{6}$ spores $/ g$ of dried soil before transplanting.

To determine the effect of soil $\mathrm{pH}$ on clubroot suppression by $H$. chaetospira, portions of each of the infested soil mixtures were adjusted to one of three $\mathrm{pH}$ levels $(5.5,6.3$, and 7.2) using either $1 \%$ $\mathrm{HCl}$ or $10 \% \mathrm{CaCO}_{3}$. The All soils were maintained at $60 \%$ moisture content.

To determine the effect of soil moisture on the suppression of club root by $H$. chaetospira, portions of each of the infested soil mixtures were adjusted to one of three different percent moisture holding capacities $(40,60$, and 80\%). Soil $\mathrm{pH}$ for all treatments was adjusted to 5.5.

Disease symptoms were assessed 1 month after transplanting using the disease index (DI) previously reported by Yoshikawa et al. (16) with slight modifications. Clubroot severity was visually separated into four classes: 0 (no swelling visible), 1 (very slight swelling, usually confined to lateral roots), 2 (moderate swelling on lateral or tap roots), and 3 (severe swelling on lateral or tap roots). The number of plants in class 0 was multiplied by 0 , in class 1 by 10 , in class 2 by 60 , and in class 3 by 100 , and the sum was divided by the total number of plants to give a DI. Five plants (one/pot) in each treatment (soil $\mathrm{pH}$ and soil moisture regime) were recovered to assess the disease symptoms. The entire experiment was conducted three times.

Disease suppression in the field. Field experiments were conducted at Iwama, Ibaraki, Japan. In all, three experimental plots (each of approximately $50 \mathrm{~m}^{2}$ ) with different soil moisture conditions were set up to examine the effect of $H$. chaetospira on clubroot disease. Soils in all three plots were haplic andosols derived from volcanic ash soil and humus. The soil moisture content was measured with a $\mathrm{pF}$ meter (DIK 8332; Daiki Rika Kogyo Co. Ltd., Shiga, Japan) and was adjusted by controlling watering with an automatic watering system (JMT-100; KITZ Co. Chiba, Japan). The $\mathrm{pF}$ level was assessed by capillary force and indicated soil moisture content. In the field, a suitable $\mathrm{pF}$ range for plant growth generally is $\mathrm{pF} 1.7$ to 2.3 . Therefore, we adjusted $\mathrm{pF}$ values in plots 1,2 , and 3 to be high (pF 1.6 to 1.8 ), moderate ( $\mathrm{pF} 2.0$ to 2.2 ), and low ( $\mathrm{pF} 2.2$ to 2.4) relative to the suitable $\mathrm{pF}$ range for plant growth. The concentrations of resting spores of $P$. brassicae were adjusted as uniformly as possible to approximately $10^{5}$ spores/g of soil in the upper $20 \mathrm{~cm}$ of the soil horizon by either adding a resting spore suspension of the pathogen or by removing infested soil. After the adjustment, the number of resting spores per gram of soil was estimated using a modification of the procedure of Takahashi and Yamaguchi (12). Five soil samples (20 g) were randomly selected from each field, mixed with $400 \mathrm{ml}$ of Tween 20 (0.05\%), shaken for $1 \mathrm{~min}$ on a shaker, and sieved (50- $\mu \mathrm{m}$ final mesh size) to remove coarse particles. The filtrate then was centrifuged (3,000 rpm for $10 \mathrm{~min})$ and the resultant precipitate was suspended in $100 \mathrm{ml}$ of SDW prior to being mixed with calcofluor white MR2 $\left(100 \mathrm{~g} \mathrm{ml}^{-1}\right)$. Spores were quantified under a fluorescence microscope (Olympus BX50) with UPlanFI40/ 0.75 objectives.

To measure the soil $\mathrm{pH}$ in the field, five soil samples (20 g each) were selected randomly from each plot, air dried, ground in a mortar, and passed through a 2-mm sieve. $\mathrm{pH}$ measurements were made using a glass electrode at a soil:water ratio of 1:2.5 according to Narisawa et al. (10).

Each plot was subdivided into two equal strips. Each strip was subdivided into a row of four cells (subplots) so that all plants of one cell were inoculated with the endophyte while all plants of the adjoining two cells were uninoculated controls. Inoculated cells alternated in both rows and pairs with controls. Eight cells were set up for each plot. Approximately 250 Chinese cabbage were planted in each plot.

Three-week-old Chinese cabbage seedlings were transplanted to each of the three plots at the beginning of September 2002. Disease symptoms and the number of dis- 
eased plants were assessed approximately 2 months after transplanting. Thirty plants in each of the cells were selected at random and classified using the DI of Yoshikawa et al. (16) with slight modifications: $0=$ no swelling visible; 1 = very slight swelling, usually confined to lateral roots; $2=$ moderate swelling on lateral or tap roots; $3=$ severe swelling on lateral or tap roots; and $4=$ severe swelling on decayed lateral or tap roots. The DI was calculated by adding the products obtained as follows: in class $0(\times 0)$, in class $1(\times 10)$, in class $2(\times 30)$, in class $3(\times 60)$, and in class $4(\times 100)$, and dividing the products by the total number of plants.

Data analyses. The proportion of diseased plants, disease indices, and mean weights were analyzed for significance using an analysis of variance (ANOVA) with the Abacus Concept StatView procedure (Abacus Concept, Inc., Berkeley, CA). Following detection of significance in the ANOVAs, Fisher's protected least significant difference tests were performed to ascertain where significant differences between treatments and controls occurred. All percentage data were arcsin transformed before analyses.

\section{RESULTS}

Root colonization by $H$. chaetospira. Before transplanting, the average percentage of root colonization of the seedlings by H. chaetospira was $78 \%$. Fungal hyphae developed well in cortical cells but they did not form pigmented cells or irregularly lobed, rounded, thick-walled cells referred to as microsclerotia. After pot and field experiments, the average percentage of root colonization of plants by the endophyte was estimated again and confirmed as $H$. chaetospira. Colonization frequencies ranged from 27 to $36 \%$. There was no relationship between the frequency of root colonization of the fungus and the biocontrol effect under different pathogen densities, soil moisture regimes, or soil $\mathrm{pH}$ conditions.

Disease suppression in the greenhouse. At a pathogen spore density of $10^{5}$ spores/g of soil, the average DI in control plants at soil pHs of 5.5, 6.3, and 7.2 was 63, 40, and 29, respectively (Fig. 1B), representing a significant reduction in disease symptoms with increasing $\mathrm{pH}$. Most control plants were moderately to severely diseased and had large or small galls on lateral and tap roots. A similar decline in disease development with increasing $\mathrm{pH}$ was observed at a pathogen spore density of $10^{4}$ spores/g of soil. However, at a spore density of $10^{6} / \mathrm{g}$ of soil, all plants were severely diseased, regardless of $\mathrm{pH}$ or $\mathrm{H}$. chaetospira treatment (Fig. 1C).

At pathogen spore densities of $10^{4}$ and $10^{5}$ spores/g of soil, the average DI in $H$. chaetospira-treated pants was uniformly low (0 to 6) at all soil pHs, representing reductions in the disease of 90 to $100 \%$ compared with control plants (Fig. 1B). These plants appeared healthy and had no or a few galls confined mostly to lateral roots. However, when the pathogen spore density was $10^{6}$ spores/g of soil, treatment with $H$. chaetospira had no effect on clubroot disease indices. All control and $H$. chaetospira-treated plants consistently showed severe disease symptoms and had disease indices of 100 (Fig. 1C).

Soil moisture content greatly affected the disease level of the plant. At a pathogen spore density of $10^{4}$ spores/g of soil, the average DI in control plants increased dramatically (40 to $80 \%$ ) along the soil moisture gradient with values of 5, 49, and 100, at 40,60 , and $80 \%$, respectively (Fig. 2A). Similarly, when the pathogen spore density was $10^{5}$ spores/g of soil at soil moisture contents of 40,60 , and $80 \%$, the disease in control plants increased substantially with increasing soil moisture content (Fig. 2B). However, at $10^{6}$ spores/g of soil, all plants were severely diseased at 60 and $80 \%$ soil moisture content; whereas, at $40 \%$ soil moisture content, the DI remained low ( $<20$; Fig. 2C). Most control plants at 60 and $80 \%$ soil moisture contents were moderately to severely diseased and had large or small galls on lateral and tap roots.
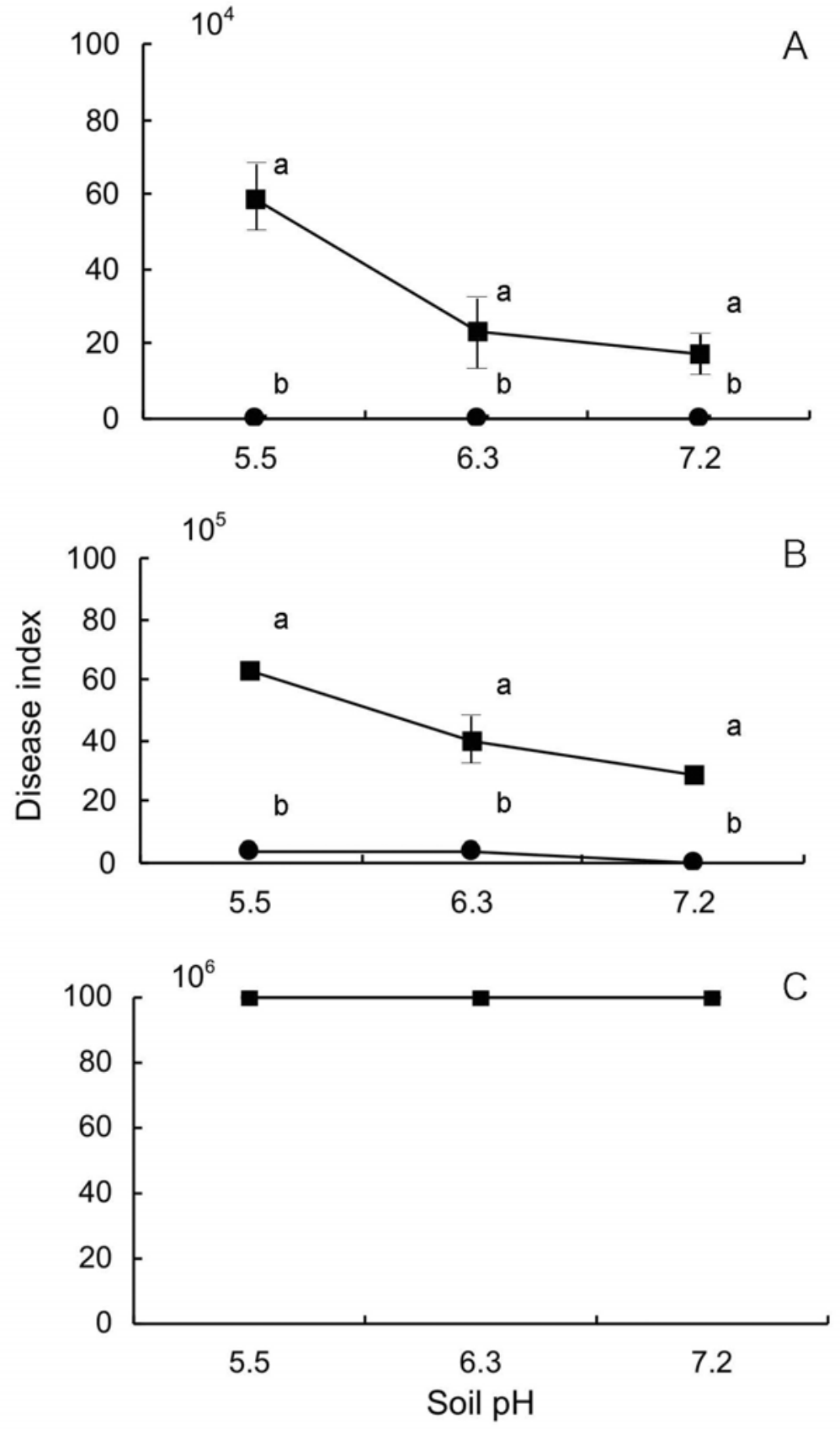

Fig. 1. Effects of soil $\mathrm{pH}$ and pathogen resting spore densities $\left(10^{4}\right.$ to $10^{6} \mathrm{spores} / \mathrm{g}$ of soil) on the development of clubroot in Chinese cabbage ( $\mathbf{\square}=$ Heteroconium chaetospira treatment, $\boldsymbol{\bullet}=$ control). Symbols with the same letter within each resting spore density regime were not significantly different according to Fisher's protected least significant difference test at $P=0.05$. 
In $H$. chaetospira-treated pants, disease development was influenced by soil moisture content as well. When the pathogen spore density was $10^{4}$ spores/g of soil, the average disease indices in $H$. chaetospira- treated plants at soil moisture contents of 40 and $60 \%$ remained very low (0 to 4$)$, representing a disease reduction of 100 and $92 \%$, respectively (Fig. 2A). Similarly, when the pathogen spore density was $10^{5}$
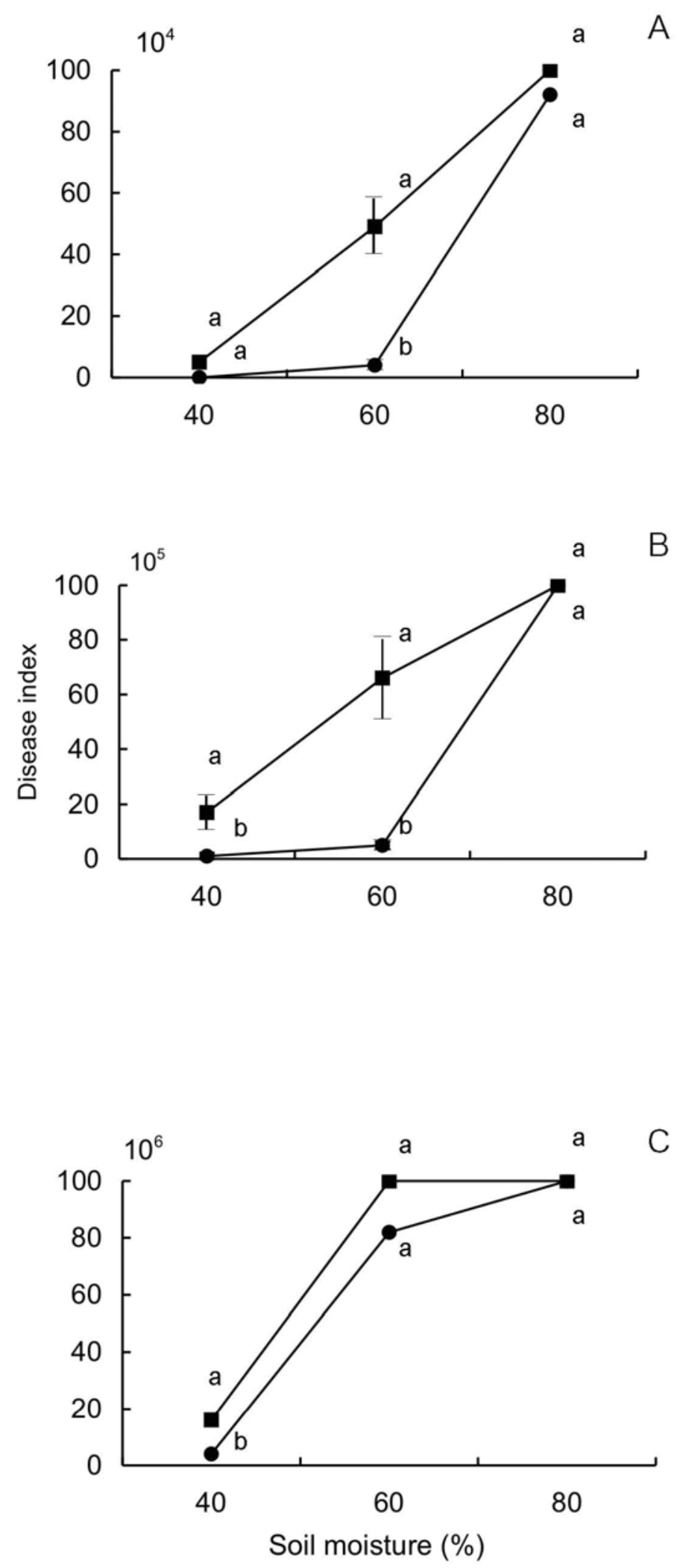

Fig. 2. Effects of soil moisture and pathogen resting spore densities $\left(10^{4}\right.$ to $10^{6} \mathrm{spores} / \mathrm{g}$ of soil) on the development of clubroot in Chinese cabbage ( $\mathbf{\square}=$ Heteroconium chaetospira treatment, $\boldsymbol{\bullet}=$ control). Symbols with the same letter within each resting spore density regime were not significantly different according to Fisher's protected least significant difference test at $P=0.05$.

spores/g of soil at a soil moisture content of 40 and $60 \%, H$. chaetospira-treated plants displayed very low disease indices (1 to 5), which represented a 94 and $92 \%$ reduction in the disease, respectively (Fig. 2B). Most $H$. chaetospira-treated plants at soil moisture contents of 40 and $60 \%$ appeared healthy and had no or a few galls confined to mostly lateral roots. However, $H$. chaetospira could not effectively suppress clubroot development at $80 \%$ soil moisture content at any pathogen inoculum density. Likewise, when the pathogen spore density was $10^{6}$ spores/g of soil, $H$. chaetospira effectively suppressed clubroot development only at a soil moisture content of $40 \%$, which represented a $75 \%$ reduction, but was not effective at soil moisture contents of 60 or $80 \%$ (Fig. 2C).

Disease suppression in the field. Resting spore densities were $6.8,2.3$, and $6.3 \times$ $10^{5} \mathrm{spores} / \mathrm{g}$ of soil and soil $\mathrm{pH}$ was 5.6 , 5.5 , and 5.3 in plots adjusted to soil moisture contents of $\mathrm{pF} 2.2$ to $2.4,2.0$ to 2.2 , and 1.6 to 1.8 , respectively. Under these conditions, most control plants in all plots were extremely wilted before maturity and had large galls on lateral and tap roots (Table 1). In H. chaetospira-treated plants, disease development was influenced by soil moisture content. H. chaetospiratreated plants at soil moisture contents of $\mathrm{pF} 2.2$ to 2.4 and 2.0 to 2.2 effectively reduced the disease symptoms of clubroot compared with control plants by 68 and $49 \%$, respectively (Table 1 ). All H. chaetospira-treated plants at soil moisture content of pF 2.2 to 2.4 appeared healthy and had only a few galls confined mostly to lateral roots. Chinese cabbage plants inoculated with $H$. chaetospira in situ had fresh weights $4.2 \times$ greater than the uninoculated control plants (Table 1). Although most $H$. chaetospira-treated plants were not wilted at a soil moisture content of $\mathrm{pF} 2.0$ to 2.2, some were wilted, and those damaged plants had many galls on the lateral and tap roots. At a soil moisture content of $\mathrm{pF} 2.0$ to 2.2, Chinese cabbage plants inoculated with the endophyte had fresh weights $2.4 \times$ greater than the control plants. However, at a soil moisture content of $\mathrm{pF} 1.6$ to $1.8, \mathrm{H}$. chaetospira was not effective against clubroot, with all plants severely damaged, without compact heads, and with large galls on lateral and tap roots. The DI for the symptoms of clubroot with the endophyte was actually higher than in control plants and had fresh weights $0.6 \times$ that of the control plants.

\section{DISCUSSION}

We demonstrated for the first time the effects of soil moisture and $\mathrm{pH}$, and pathogen density, on the effectiveness of the biological control of clubroot by the fungal endophyte $H$. chaetospira. Inconsistencies in the biocontrol of crop diseases under varying environmental conditions have been a common limitation of many biocon- 
trol agents, and it is important to determine not only under which conditions the biocontrol of a disease agent is successful, but also under which conditions it is not (7). Although a few attempts had been made to develop biological methods for controlling clubroot using soil fungi $(1)$, bacteria $(3,4)$, or fungal endophytes (10), these previous studies did not address optimal environmental conditions of their biocontrol agents for clubroot suppression.

There was a direct link between the density of $P$. brassicae resting spores in the soil and the disease severity in crop plants. Previous work has reported that clubroot development occurred at pathogen resting spore densities ranging from $10^{3}$ to $10^{8}$ spores/g of soil (9). The results of this study support those findings, because clubroot development in control plants occurred at spore densities ranging from $10^{4}$ to $10^{6}$ spores/g of soil (Figs. 1 and 2). Pathogen density affected the disease suppression by $H$. chaetospira. The endophyte almost completely suppressed disease at pathogen densities of $10^{4}$ and $10^{5}$ spores/g of dry soil, but was ineffective at a pathogen density of $10^{6}$ spores/g dry soil. Disease suppression by $H$. chaetospira was optimal at pathogen resting spore densities near $10^{5}$ spores/g of soil (Figs. 1 and 2).

The effects of soil $\mathrm{pH}$ on the development of clubroot in crop plants has been well established (13). For instance, although many visible galls developed on host roots in acidic soils, typical disease symptoms were absent from roots in alkaline soils at a $\mathrm{pH}$ range from 7.0 to 7.2 $(1,11)$. It appears that optimal conditions for clubroot development in roots of commercial crop plants are near $\mathrm{pH} 5.0$ (14). However, the effects of soil $\mathrm{pH}$ on clubroot development need to address additional factors, including pathogen resting spore density and soil moisture content, because host plants were severely diseased at high pathogen resting spore densities and elevated soil moisture contents, even in alkaline soils with a $\mathrm{pH}$ from 7.5 to 8.0 $(2,5,13)$. In the current work, control plants were severely diseased in alkaline soils with a high pathogen resting spore density, but not at low to moderate pathogen resting spore densities (Fig. 1), supporting previous studies. Alternatively, H. chaetospira-treated plants were not affected by the soil $\mathrm{pH}$, because $H$. chaetospira suppressed the disease almost completely from acidic to alkaline soil conditions under low to moderate pathogen resting spore densities $\left(10^{4}\right.$ to $10^{5}$ spores/g of soil; Fig. 1). Therefore, optimal conditions for $H$. chaetospira to suppress clubroot (i.e., the highest percent reduction in the disease severity) appear to be near $\mathrm{pH} 5.5$.

Soil moisture content strongly affected the development of clubroot. At optimal soil moisture conditions, damage on host plants ranged from 70 to $80 \%$, but no typical symptoms of clubroot developed under $45 \%$ soil moisture content (8). In the current work, control plants were severely diseased at a high soil moisture content $(80 \%)$ but not under low moisture content (40\%) (Fig. 2), supporting previous findings. Similarly, $H$. chaetospira-treated plants were almost completely protected from clubroot at low to moderate soil moisture contents (40 to $60 \%$ ), but they were severely damaged at high soil moisture contents (80\%) (Fig. 2). Therefore, the optimal soil moisture content for the suppression of clubroot by the root endophyte appears to be near $60 \%$.

Based on these in vitro experiments, we examined the effectiveness of $H$. chaetospira on the suppression of clubroot under varying soil moisture conditions in the field. To this end, environmental conditions were adjusted in all plots to 6.8, 2.3, and $6.3 \times 10^{5}$ spores/g of soil ("severe") and pHs of 5.6, 5.5, and 5.3 ("acidic") in plots 1,2 , and 3, respectively. Our study showed that $H$. chaetospira-treated plants were able to suppress clubroot under relatively low to moderate soil moisture contents (pF 2.0 to 2.4), but that they were severely damaged under high soil moisture contents (pF 1.6 to 1.8 (Table 1). Such high soil moisture contents negatively affect normal plant growth and do not occur naturally unless a typhoon or heavy precipitation events occur post transplanting.

The clubroot pathogen $P$. brassicae produces flagellated zoospores from germinating resting spores and zoosporangial zoospores (6), both of which may be active in the soil and may vigorously infect host roots under high soil moisture conditions. This may result in severe disease outbreaks. Therefore, the activity of zoospores at high soil moisture contents may cause the same effect as the presence of high pathogen resting spore densities in the soil (i.e., the development of disease symptoms). Consequently, the most important environmental factor for the suppression of clubroot in situ is likely the pathogen resting spore density, which is supported by our findings in vitro as well (Figs. 1 and 2).

Based on our results, we recommend the use of $H$. chaetospira as a clubroot biocontrol agent in Chinese cabbage if the pathogen resting spore density is less than $10^{5}$ spores/g of soil. As previously mentioned, the percentage of clubbed plants and DI increased gradually with spore density. The minimum spore density required to produce clubbed roots was more than 3.55 spores/g of soil and the plants produced severe clubs even at a spore density of $10^{3}$ spores/g of soil (9). In fact, when the pathogen spore density was estimated in some commercially cultivated infested fields, it was generally less than $10^{5}$ spores/g of soil (data not shown). Therefore, a spore density of less than $10^{5}$ spores/g of soil appears to be representative of most commercial fields. In order to succeed in the biocontrol of clubroot, we need to estimate the density of resting spores prior to transplanting $H$. chaetospira-treated plants. In addition, the suppressive effect of $H$. chaetospira will increase if crop plants are grown under suitable draining conditions.

\section{ACKNOWLEDGMENTS}

We thank M. N. Thormann, Natural Resources Canada, Canadian Forest Service, Northern Forestry Centre, Edmonton, Alberta, Canada, for critically reviewing the manuscript.

\section{LITERATURE CITED}

1. Djatnika, I. 1991. Prospects of biological control of clubroot. Cruciferae Newsl. 14-15:142.

2. Einhorn, G., Bochow, H., Huber, J., and Krebs, B. 1991. Methodological studies to detect antagonists of the clubroot pathogen Plasmodiophora brassicae Wor. Arch. Phytopathol. Pflanzenschutz 27(3):205-208.

3. Elsherif, M., and Grossmann, F. 1991. Investigations on biological control of some plant pathogenic fungi by fluorescent pseudomonads using different methods of application. J. Plant Dis. Prot. 98(3):236-249.

4. Harling, R., and Kennedy, S. H. 1991. Biological control of Plasmodiophora brassicae using a bait crop. Meded. Fac. Landbouwwet. Rijksuniv. Gent. 56(2a):159-170.

5. Horiuch, S., and Hori, M. 1980. A simple greenhouse technique for obtaining high levels clubroot incidence. Bull. Chugoku Natl. Agric Exp. Stn. E17:33-55.

6. Ingram, D. S., and Tommerup, I. C. 1972. The life history of Plasmodiophora brassicae. Proc. R. Soc. Lond. Sect. B 180:103-112.

7. Larkin, R. P., and Fravel, D. R. 2002. Effect of varying environmental conditions on biological control of Fusarium wilt of tomato by nonpathogenic Fusarium spp. Phytopathology 92:1160-1166.

Table 1. Effects of Heteroconium chaetospira on the incidence of clubroot in Chinese cabbage plants at different soil moisture conditions in the field

\begin{tabular}{|c|c|c|c|c|c|c|c|c|c|}
\hline \multirow{3}{*}{ Treatments } & \multicolumn{9}{|c|}{ Soil moisture ${ }^{z}$} \\
\hline & \multicolumn{3}{|c|}{ Low (pF 2.2-2.4) } & \multicolumn{3}{|c|}{ Moderate (pF 2.0-2.2) } & \multicolumn{3}{|c|}{ High (pF 1.6-1.8) } \\
\hline & Pdp & DI & Mw & Pdp & DI & $\mathbf{M w}$ & Pdp & DI & Mw \\
\hline H. chaetospira & $79 \mathrm{a}$ & $25 \mathrm{~b}$ & $1,501 \mathrm{~b}$ & $67 \mathrm{~b}$ & $41 \mathrm{~b}$ & $910 \mathrm{~b}$ & $99 \mathrm{a}$ & $86 \mathrm{a}$ & $340 \mathrm{a}$ \\
\hline Control & $85 \mathrm{a}$ & $78 \mathrm{a}$ & $356 \mathrm{a}$ & $88 \mathrm{a}$ & $80 \mathrm{a}$ & $373 a$ & $97 \mathrm{a}$ & $72 \mathrm{a}$ & $618 \mathrm{~b}$ \\
\hline
\end{tabular}

${ }^{\mathrm{z}} \mathrm{pF}$ is a unit of pressure, given with $\mathrm{pF}=\log (\mathrm{kPa} \times 10.197), \mathrm{Pdp}=$ proportion of diseased plants $(\%)$, DI $=$ disease index $(0$ to 100$)$, and $\mathrm{Mw}=\mathrm{mean}$ weight $(\mathrm{g})$ of 30 plants. Values followed by the same letter are not significantly different at $P=0.05$, Fisher's protected least significant difference test. 
8. Monteith, J. 1924. Relation of soil temperature and soil moisture to infection by Plasmodiophora brassicae. J. Agric. Res. 28:549561.

9. Naiki, T., Kageyama, K., and Ikegami, H. 1978. The relation of spore density of Plasmodiophora brassicae Wor. to root hair infection and clubroot formation in Chinese cabbage. Ann. Phytopathol. Soc. Jpn. 44:432439.

10. Narisawa, K., Ohki, T., and Hashiba, T. 2000. Suppression of clubroot and Verticillium yellows in Chinese cabbage in the field by the endophytic fungus, Heteroconium chaetospira.
Plant Pathol. 49:141-146.

11. Narisawa, K., Tokumasu, S., and Hashiba, T. 1998. Suppression of clubroot formation in Chinese cabbage by root endophytic fungus, Heteroconium chaetospira. Plant Pathol. 47:210-216.

12. Takahashi, K., and Yamaguchi, T. 1987. An Improved method for estimating the number of resting spores of Plasmodiophora brassicae in soil. Ann. Phytopathol. Soc. Jpn. 53:507-515.

13. Tamura, M. 1977. Ecological study on Plasmodiophora brassicae in Chinese cabbage. Plant Prot. 31:362-366.

14. Tamura, M., and Taketani, K. 1977. Ecological study on control of clubroot in Chinese cabbage in Ishikawa prefecture. Bull. Ishikawa Agric. Exp. Stn. 9:1-26.

15. Usuki, F., Narisawa, K., Yonezawa, M., Kakishima, M., and Hashiba, T. 2002. An Efficient inoculation method for colonization of Chinese cabbage seedlings by the root endophytic fungus Heteroconium chaetospira. J. Gen. Plant Pathol. 68:326-332.

16. Yoshikawa, H., Ashizawa, M., and Hida, K. 1977. Pathogenic races of Plasmodiophora brassicae in Japan. Pages 80-86 in: Proc. Woronin +100 Conf. University of Wisconsin Madison. 